\title{
Assessment of Industrial Effluents Quality and their Possible Impact on Surface Water
}

\author{
Florina COPACIU ${ }^{1)}$, Carmen ROBA ${ }^{2) *}$, Ocsana OPRIŞ ${ }^{3)}$, Andrea BUNEA ${ }^{1)}$ and Vioara MIREŞAN ${ }^{1)}$ \\ 1) Faculty of Animal Science and Biotechnologies, University of Agricultural Sciences and Veterinary \\ Medicine, 400372 Cluj-Napoca, 3-5 Mănăştur Street, Romania \\ ${ }^{2)}$ Faculty of Environmental Science and Engineering, Babeş-Bolyai University, 400294 Cluj-Napoca, 30 \\ Fântânele Street, Romania \\ ${ }^{3)}$ National Institute for Research and Development of Isotopic and Molecular Technologies, Cluj- \\ Napoca, 67-103 Donat Street, 400293, , Romania \\ *Corresponding author, e-mail: carmen.roba@ubbcluj.ro
}

Bulletin UASVM Animal Science and Biotechnologies 72(2) / 2015

Print ISSN 1843-5262; Electronic ISSN 1843-536X

DOI:10.15835/buasvmcn-asb:11436

\begin{abstract}
The printing, textile, wood and plastics industries have an important environmental impact, since they consume large amounts of water and produce highly polluted waste waters (Sostar-Turk et al., 2005). The current study aimed to investigate several effluents generated by different industries based on their physicochemical parameters and to evaluate their possible impact on the water body. Effluents from two printing, a textile, a wood and a plastics industry from Cluj County were analysed for various physicochemical parameters such as temperature, $\mathrm{pH}$, biochemical and chemical oxygen demand, total dissolved solids, total suspended solids, total nitrogen, total phosphorus, ammonium, chloride, sulphate, petroleum ether extractible substances, and detergents. The samples were analysed using the corresponding standard procedures SR ISO 105523-97, SR ISO 1899/1-03, SR ISO 6060-96, STAS 9187-84, STAS 6953-81, Merck 14543, Merck 14537, SR ISO 7150/1-01, EPA 375.4/05, SR IS 9297-01, SR ISO 7150/1-01, and SR EN 903-03. The temperature, total dissolved solids, chloride, sulphate and detergent content of the effluents were within the permissible limits for surface water discharge, while the other parameters exceeded the limit set by legislation. The data of the present study showed that the analysed physicochemical parameters significantly varied with the effluent source. The study indicated a seasonal variation for several parameters, dictated by the production schedule of the manufacturer. In many cases, the quality of the studied effluents was below the limits set by Romanian and UE legislation.
\end{abstract}

Keywords: azo-dye related industries, physicochemical parameters, textile effluents, toxic effects

\section{INTRODUCTION}

A serious problem in developing countries is the inadequate management of waste waters generated by several anthropogenic activities. Owing to the increased need for printing, textile, furniture and plastics products, these industries and the amount of the generated waste waters have increased proportionally, becoming important water polluters (Adewoye, 2010; Roșu et al., 2015). From the above mentioned industries, textile manufacturing is the major water consumer, generating high amounts of waste waters. The textile and printing effluents have a complex composition due to the usage of a variety of chemicals, which include dyes, detergents, insecticides, pesticides, grease and oils, solvents, heavy metals or inorganic salts (Sostar-Turk et al., 2005). These effluents often have strong colour, high chemical and biochemical oxygen demand, suspended solids, salts, and highly fluctuating pH (Hannan et al., 2011). The wood industry uses different kinds of materials, such as paints, wood treatments, stains, varnishes, polishes, and adhesives. As a consequence, the wood industry 
generates a diversity of residues, including wood residues, metal, plastic, glass, fabric, glues, organic solvents, removers, paints and varnishes. The quantities and characteristics of the generated residues depend on the raw material and product nature, on the water consumption and on the average daily production (Roy et al., 2010). Environmental problemsassociated with the textile and dye-related industries are mainly caused by waste water treatment and discharge (Hannan et al., 2011). A number of studies (Wells et al., 1994; Mathur et al., 2005) have demonstrated that these effluents contain chemicals with genotoxic and mutagenic activity, and are a real threat to public health. Some of these toxic compounds cannot be removed by conventional waste water treatment methods and they are highly stable, accumulating through food chain and causing deleterious biological effects (Kannan et al., 2005).

The objectives of the present study were to characterize several dye-using industry effluents generated by two printings, one textile, one furniture and one plastic products plant, by analysing their $\mathrm{pH}$, biochemical oxygen demand (BOD), chemical oxygen demand (COD), total dissolved solids (TDS), total suspended solids (TSS), total phosphorus (TP), total nitrogen (TN), ammonium $\left(\mathrm{NH}_{4}{ }^{+}\right)$, chloride $\left(\mathrm{Cl}^{-}\right)$, sulphate $\left(\mathrm{SO}_{4}{ }^{2-}\right.$ ), petroleum ether extractible substances (PEES) and detergent content. The printing, furniture and plastic products effluents were discharged into the Someș River after they had been treated using conventional treatment methods, while the textile effluents were discharged into the sewerage system after prior treatment. Based on the analysed parameters, the possible impact on the Someş River of the effluent withdrawal was evaluated. The effluents were monitored during 2007 and 2011 in order to establish the monthly and seasonal correlations between various parameters at different sites. The levels of the analysed physicochemical parameters were compared with the permissible limits for surface water discharge set by Romanian and UE legislation. The Council Directive 91/271/ EEC regarding municipal waste water treatment was entirely adopted in Romanian legislation by Governmental Decision no. 188/2002 (amended by Governmental Decision no 352/2005, with Annex no. 2 - NTPA 002/2005 and Annex no. 3 NTPA 001/2005) for the approval of special norms regarding the conditions of waste water discharge in aquatic environments.

\section{MATERIALS AND METHODS}

Site selection and sampling

The investigated industries are located in Cluj County, in north-western Romania. The Cluj County water network comprises three basins: the Someș, the Crişul Repede and the Mureș. The main industries in Cluj County are: mechanical components, wood processing, textiles, plastics processing, glass manufacturing, pharmaceutics, cosmetics, and food stuffs processing. The discharge of the effluents generated by these industries into surface waters can have a negative impact especially on the perimeter covered by the Someşul Mic Basin, which is the principal receptor of these effluents. The general characteristics of the investigated companies are summarized in Table 1.

Tab. 1. The general characteristics of the evaluated companies

\begin{tabular}{ccccc}
\hline Company & Founded & Employees & Size & Main activity \\
\hline Printing 1 & 2006 & $50-100$ & medium & $\begin{array}{c}\text {-flexible packaging for food } \\
\text {-bags }\end{array}$ \\
\hline Printing 2 & 1994 & $6-10$ & $\begin{array}{c}\text { micro/ } \\
\text { small }\end{array}$ & $\begin{array}{c}\text {-magazines } \\
\text {-flyers }\end{array}$ \\
\hline Textile & 2000 & $64-78$ & medium & $\begin{array}{c}\text {-clothing (sweaters, skirts, pants, jackets) } \\
\text {-footwear }\end{array}$ \\
\hline Furniture & 2003 & 240 & medium & $\begin{array}{c}\text {-wood processing } \\
\text {-furniture manufacturing for external market }\end{array}$ \\
\hline Plastics & 1955 & 400 & big & $\begin{array}{c}\text {-plastic processing for kitchen, bathroom, } \\
\text { garden, packing and bottle }\end{array}$ \\
$\begin{array}{l}\text { *Size defined according to the classification of Law no. 133 of 20 july 1999: micro companies - from 1 to 9 employees; small } \\
\text { companies - from 10 to 49 employees; medium companies - from 50 to 249 employees; big companies - over 250 employees. }\end{array}$
\end{tabular}




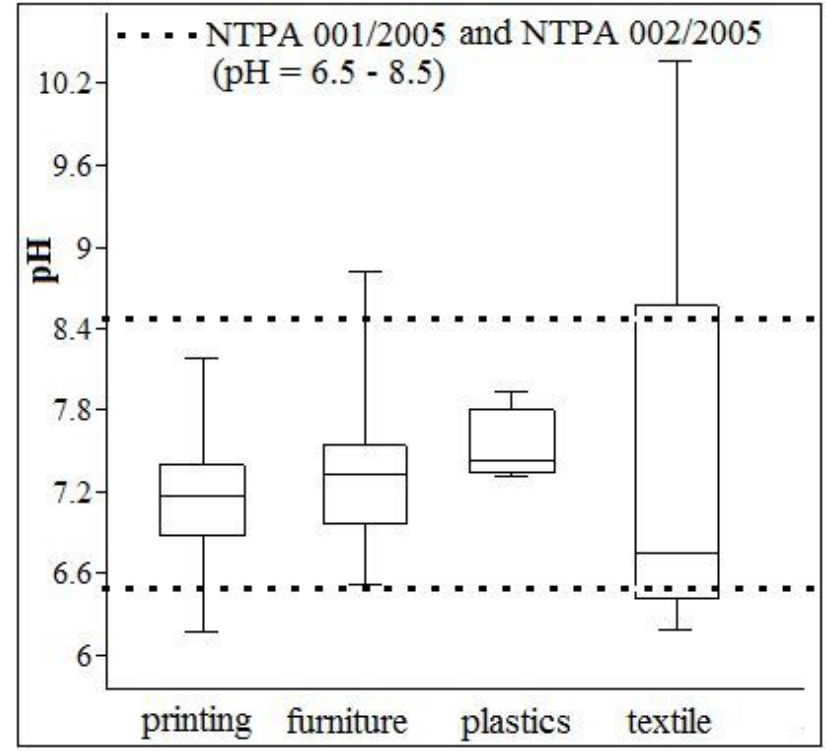

Fig. 1. The $\mathrm{pH}$ of the analysed effluents

We collected our samples at the location where effluents are discharged into the Someșul Mic River. These samples were collected in plastic recipients previously washed with nonionic detergent and rinsed with distilled water. After the labelling and transportation of the samples to the laboratory, these were stored at $4^{\circ} \mathrm{C}$ away from sunlight and analysed within 24 hours from sampling. The effluent samples were collected during May 2007 and April 2011 (for printing), between March 2007 and June 2011 (for furniture), between April 2007 and December 2007 (for plastics), and during January 2011 and September 2011 (for textile).

Analysis of the physicochemical parameters

The collected samples were analysed for the following physicochemical parameters: $\mathrm{pH}$, COD, BOD, TSS, TDS, TP, TN, $\mathrm{NH}_{4}^{+}, \mathrm{SO}_{4}^{2-}, \mathrm{Cl}$, PEES, and detergents content using the corresponding standard procedures SR ISO 105523-97, SR ISO 1899/1-03, SR ISO 6060-96, STAS 9187-84, STAS 6953-81, Merck 14543, Merck 14537, SR ISO 7150/1-01, EPA 375.4/05, SR IS 9297-01, SR ISO 7150/1-01, SR EN 903-03.

\section{RESULTS AND DISCUSSION}

$p H$

The water $\mathrm{pH}$ influences most of the chemical and biochemical reactions. As a consequence, the effluents' pH modify the water's physical-chemical properties with a significant impact on aquatic life (Nosheen et al., 2005).
The effluents' $\mathrm{pH}$ values obtained in the present paper were between 6.17 and 10.35 , with a slightly alkaline value. Only the plastic effluents had the $\mathrm{pH}$ level (7.31 - 7.92) within the admitted value of 6.5 to 8.5 prescribed by legislation (Figure 1). In both printing and furniture effluents, the $\mathrm{pH}$ was within the admitted value with one exception. The highest $\mathrm{pH}$ variance $(6.18$ - 10.35) was registered in the textile effluents, where several samples exceeded the lower and upper limits for effluent disposal into surface water. A high $\mathrm{pH}$ value recorded in the textile effluents presents a risk for the aquatic life, because a $\mathrm{pH}$ value over 8.5 inhibits the growth of the aquatic macrophytes by impairing iron and phosphorus uptake and reducing fish production (Argo, 2003).

Chemical and biological oxygen demand

COD represents the quantity of oxygen needed by both potassium dichromate and concentrated sulphuric acid for breaking down inorganic and organic matters existing in water. BOD measures the quantity of oxygen needed by bacteria to break down the decomposable organic matter into simpler substances present in any water. High levels of BOD indicate the pollution strength of the waste waters and the low level of oxygen available for living organisms. High COD levels imply toxic conditions and the presence of biologically resistant organic substances.

The data of the present study showed that the values of COD and BOD varied significantly with the effluent source. The highest COD values were registered in the textile effluents $(1812.5$ - 6481 $\mathrm{mg}_{2} / \mathrm{l}$, with a mean value of $4488 \mathrm{mg} \mathrm{O}_{2} / \mathrm{l}$ ), while the printing ( 37.8 - $346 \mathrm{mg} \mathrm{O}_{2} / \mathrm{l}$, with a mean value of $93.9 \mathrm{mgO}_{2} / \mathrm{l}$ ), furniture (50.1 - $129.2 \mathrm{mg} \mathrm{O}_{2} / \mathrm{l}$, with a mean value of $105 \mathrm{mg} \mathrm{O}_{2} / \mathrm{l}$ ) and plastic (72 - $81.6 \mathrm{mg} \mathrm{O}_{2} / \mathrm{l}$, with a mean value of $76.7 \mathrm{mg}$ $\mathrm{O}_{2} / \mathrm{l}$ ) effluents had a considerably lower COD level (Fig. 2).

The BOD level was lower than the COD and it had a relatively similar variation with the exception of the plastic effluents. The BOD level was lower in the printing ( $\left.8.22-45.3 \mathrm{mg} \mathrm{O}_{2} / \mathrm{l}\right)$ and furniture (24.16 - $32.13 \mathrm{mg} \mathrm{O}_{2} / \mathrm{l}$ ) effluents compared to the plastic $\left(220-240 \mathrm{mg} \mathrm{O}_{2} / \mathrm{l}\right)$ and textile (695.4 $1280.7 \mathrm{mg} \mathrm{O}_{2} / \mathrm{l}$ ) effluents.

The highest COD and BOD levels were recorded in the textile effluents, proving that these effluents have a high oxygen demand, which causes dissolved oxygen (DO) depletion. The DO 


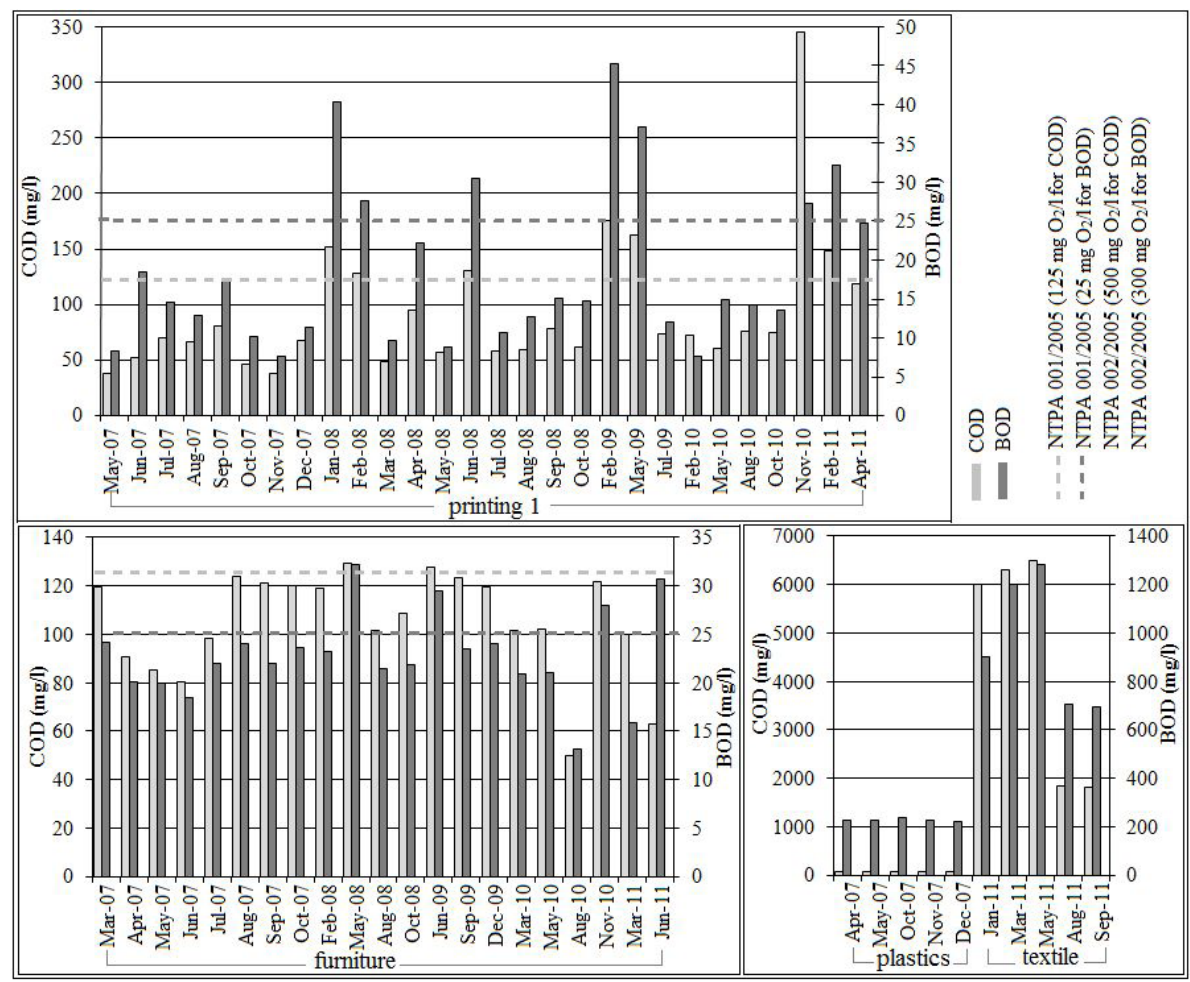

Fig. 2. Variation of chemical and biochemical oxygen demand (COD and BOD) levels in the investigated effluents

is the most important parameter of water quality (Peirce et al., 1997) and it is a fundamental requirement for aquatic life, especially for aerobic organisms. The high BOD and COD levels from the analysed effluents, which are discharged into the Someşul Mic River, can affect aerobic organism growth, which could lead to the excessive growth of anaerobic organisms and to the transformation of the water body in an uninhabitable environment for the gill-breathing aquatic organisms (Yusuff and Sonibare, 2004; Nergis et al., 2009).

\section{Total suspended and total dissolved solids}

Solids concentration represents an important waste water characteristic. The TSS content of the analysed effluents ranged between $17-126 \mathrm{mg} / \mathrm{l}$ depending on the source.

As shown in Figure 3, the highest TSS level was recorded in the effluents generated by the second printing house $(27.5-126 \mathrm{mg} / \mathrm{l})$, with its mean value of $64.8 \mathrm{mg} / \mathrm{l}$ considerably higher than the first printing TSS values ranging from 17.7 to 47 $\mathrm{mg} / \mathrm{l}$, with $25.9 \mathrm{mg} / \mathrm{l}$ as its mean, or the furniture industry values of $17-54 \mathrm{mg} / \mathrm{l}$, with their 31.9 $\mathrm{mg} / \mathrm{l}$ as mean value, or the textile industry values between $30.3-43 \mathrm{mg} / \mathrm{l}, 36 \mathrm{mg} / \mathrm{l}$ being its mean, and plastics industry values ranging from 29.8 to 51.8 $\mathrm{mg} / \mathrm{l}$, and a calculated mean of $38.8 \mathrm{mg} / \mathrm{l}$ effluents. The printing, furniture and plastic effluents exceeded the TSS effluent discharge in surface water maximum permissible limit of $35 \mathrm{mg} / \mathrm{l}$. As regards textile effluents, their TSS level is lower than $350 \mathrm{mg} / \mathrm{l}$, the sewage network admissible discharge limit. Penetration of light into water can be reduced by a high amount of suspended solids, thus suppressing photosynthetic activity of algae, phyto- plankton and macrophytes. In addition, waste water purification capacity by microorganisms will be decreased if the DO level of waste water is reduced due to deficient light penetration into water (Delee et al., 1998). The same cause can accelerate the growth of algae or increase water hardness, which in turn leads to formation of scale in pipe-lines and other equipment. The analysed effluents had a TDS relatively low level, between 310.2 - $934.4 \mathrm{mg} / \mathrm{l}$. In the furniture effluents the TDS values found ranged between 376 - $934.4 \mathrm{mg} / \mathrm{l}$, with 563.1 $\mathrm{mg} / \mathrm{l}$ as a mean value, and thus were higher than the values of 310.2 to $592.2 \mathrm{mg} / \mathrm{l}$, with $497.5 \mathrm{mg} / \mathrm{l}$ as mean, found in the printing effluents. The TDS concentrations of all the effluents were lower than 


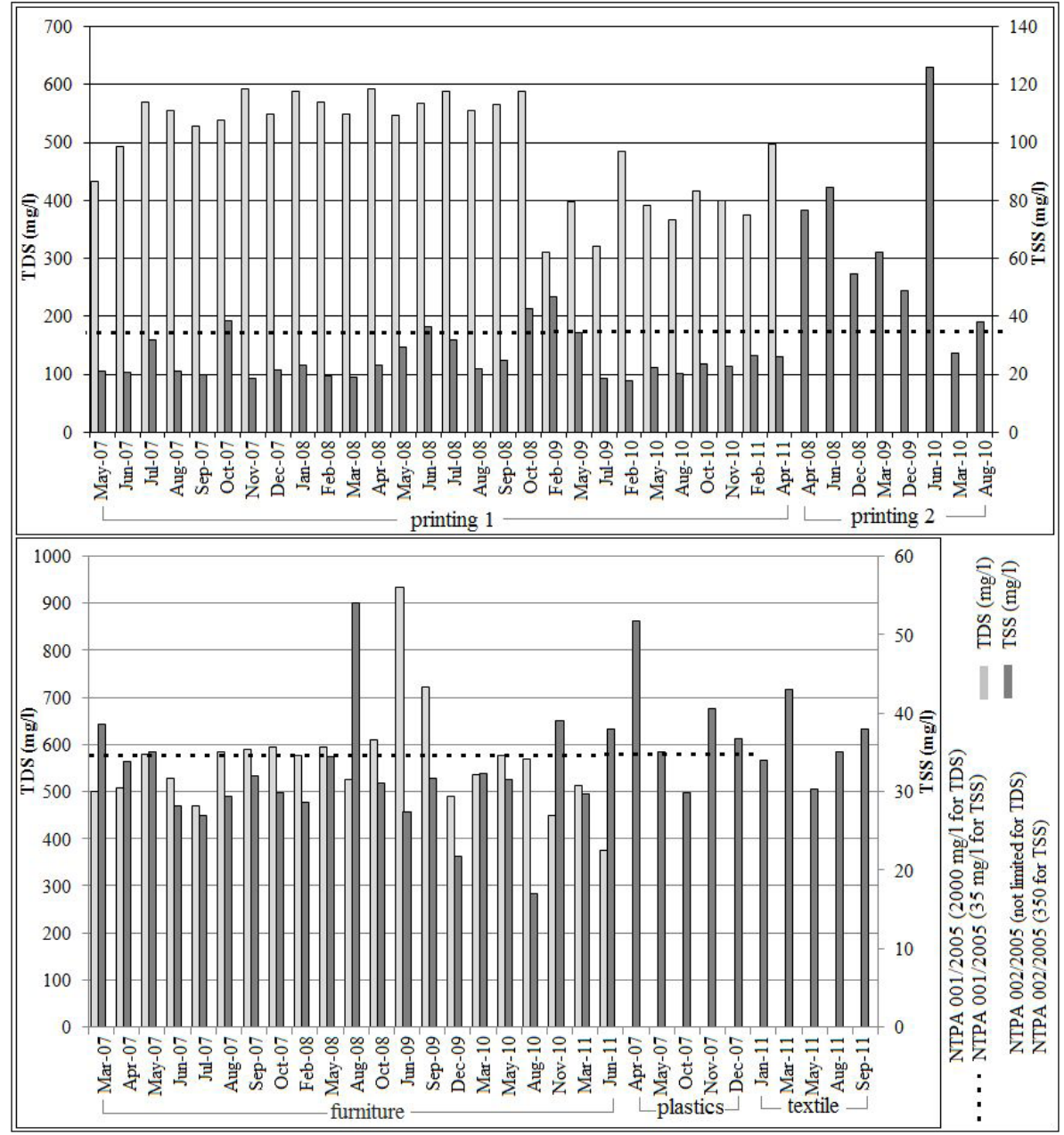

Fig. 3. Fluctuation of the total suspended and dissolved solids (TSS and TDS) levels in the investigated effluents

$2000 \mathrm{mg} / \mathrm{l}$, the permissible limit for surface water discharge.

Total nitrogen and total phosphorus

Though essential nutrients in plant growth, excessive inputs of nitrogen and phosphorus in fresh water can seriously affect the aquatic ecosystem, due to the fact that it stimulates rapid growth of algae and aquatic plants. That is why, with respect to water pollution, TN and TP are important indicators (Campbell et al., 2001; Wetzel, 2001). In our study, we found the lowest TP concentrations in the textile effluents, ranging between $0.7-2.38 \mathrm{mg} / \mathrm{l}(1.29 \mathrm{mg} / \mathrm{l}$ mean) (Fig. 4). The printing effluents had a higher TP level, between 0.05 - $5.66 \mathrm{mg} / \mathrm{l}$ (1.66 mg/l mean), while furniture effluents had the highest TP concentrations between $0.28-13.25 \mathrm{mg} / \mathrm{l}$ (2.4 $\mathrm{mg} / \mathrm{l}$ mean). Thus we found that the average TP value recorded in the case of printing and furniture effluents surpassed the permissible limit for surface water discharge $(1 \mathrm{mg} / \mathrm{l})$, while the same parameter was beneath the permissible limit for sewerage network discharge $(5 \mathrm{mg} / \mathrm{l})$ in textile effluents. For the investigated effluents, the TN level surpassed the TP one. While the textile effluents with $4.9-34.4 \mathrm{mg} / \mathrm{l}$ (15.23 mg/l mean) and the printing effluents with $1.7-29.3 \mathrm{mg} / \mathrm{l}$ (10.7 mg/l mean) had a lower concentration of TN in the furniture effluents, this ranged between $5.6-70.9 \mathrm{mg} / \mathrm{l}(15.4 \mathrm{mg} / \mathrm{l}$ mean), thus being the highest.

The permissible limit for $\mathrm{TN}$ of $10 \mathrm{mg} / \mathrm{l}$ was exceeded in printing and furniture effluents. The highest fluctuations, for both TN and TP, were recorded during 2008 and 2009 for printing effluents, and during 2010 and 2011 for furniture effluents. The peak values were recorded in the cold season (November - February) and they are 


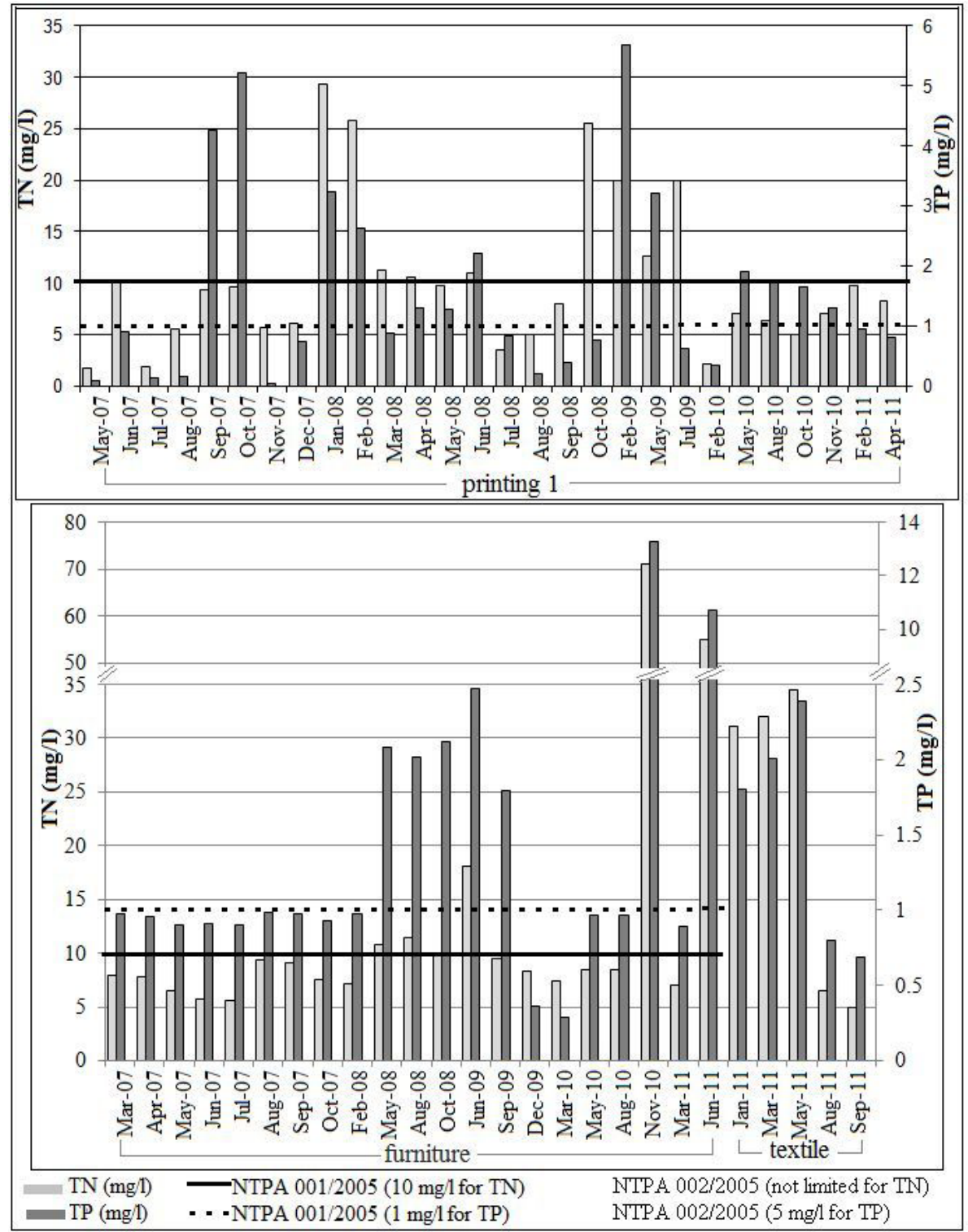

Fig. 4. The monthly fluctuation of total nitrogen (TN) and total phosphorus (TP) levels in the investigated effluents

directly correlated with the companies' production schedule.

Excess nitrogen and phosphorus can stimulate the rapid growth of aquatic plants and algae leading to water eutrophication, which has many negative effects on aquatic ecosystems including: oxygen depletion, water transparency decrease, unpleasant taste and odour, decrease in animal and plant diversity (Codd, 2000; Voutsa et al., 2001).

\section{Ammonium}

High levels of $\mathrm{TN}$ in waste water can lead to high values of free ammonia $\left(\mathrm{NH}_{3}\right)$ and ionizedammonia $\left(\mathrm{NH}_{4}^{+}\right)$, which are two forms of reduced inorganic nitrogen. The free ammonia is a gaseous chemical, whereas the ionized form remains soluble in water. The free ammonia is considerably more toxic to organisms than the ionized-ammonia (Zorpas et al., 2010).

In the present study, only the ionized-ammonia was analysed, which had a high level especially in the textile effluents $(25-38.8 \mathrm{mg} / \mathrm{l}$, with a mean value of $34.6 \mathrm{mg} / \mathrm{l}$ ) (Fig. 5).

In the furniture effluents, $\mathrm{NH}_{4}^{+}$concentration ranged between $1.2-57.6 \mathrm{mg} / \mathrm{l}$, with a mean value of $6.7 \mathrm{mg} / \mathrm{l}$, while in the printing effluents this parameter had the lowest levels, between $1.6-2.3 \mathrm{mg} / \mathrm{l}$, with a mean value of $2 \mathrm{mg} / \mathrm{l}$. The 


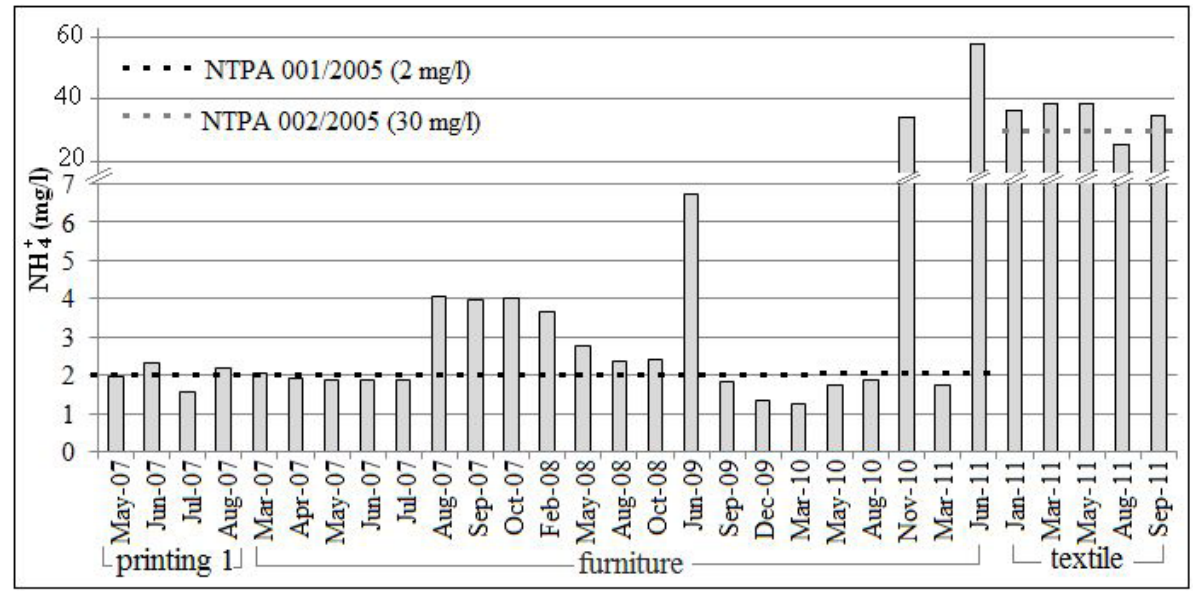

Fig. 5. The level of ammonium $\left(\mathrm{NH}_{4}^{+}\right)$in the analysed effluents

permissible limit for surface water $(2 \mathrm{mg} / \mathrm{l})$ and sewage network $(30 \mathrm{mg} / \mathrm{l})$ discharge was often exceeded in all types of effluents. For the printing and textile effluents, there were no significant fluctuations in $\mathrm{NH}_{4}^{+}$level, as compared to the furniture effluents, where significant fluctuations were recorded during 2009 and 2010.

The high $\mathrm{NH}_{4}{ }^{+}$level, recorded especially in the textile effluents, is a consequence of the high TN level of these waters. The data indicated a positive correlation, with a Pearson correlation factor (r) of 8.4, between $\mathrm{NH}_{4}^{+}$concentration and the TN level of the investigated effluents.

The slightly alkaline $\mathrm{pH}$ of the analysed effluents can change the equilibrium between the ionized and free ammonia by converting more ammonium ions into ammonia molecules, leading to high free ammonia content. Even in small quantities (under $1 \mathrm{mg} / \mathrm{l}$ ), ammonia inflicts stress and damage to gills and other tissues. Fish can have gill damage when levels reach $0.06 \mathrm{mg} / \mathrm{l}$, while at concentrations of $0.2 \mathrm{mg} / \mathrm{l}$, susceptible fish like salmon and trout die (Chambers et al., 2001). Fish exposed to low amount of ammonia in time become more sensitive to bacterial infections and may have decreased growth (Francis-Floyd et al., 1990). A major percentage of water pollution is waste water leaked by sewage and industries, which has as a consequence the increase in oxygen demand, toxic algal blooms, and which in turn cause unbalance in the aquatic ecosystem (Akan et al., 2008).

Chloride

Chloride is one of the major inorganic anions in water and waste water. High $\mathrm{Cl}^{-}$levels can destroy several micro-organisms that are significant in the food cycle of aquatic life (Kumar, 1989). Furthermore, high $\mathrm{Cl}^{-}$concentrations are corrosive for metallic pipes and the usage of these waste waters for irrigation purposes can damage agricultural crops (Nosheen et al., 2005). The $\mathrm{Cl}^{-}$content of the analysed effluents showed fluctuations within a range of $27.7-250 \mathrm{mg} / \mathrm{l}$. The printing effluents had higher $\mathrm{Cl}^{-}$content (between 48.3 - $250 \mathrm{mg} / \mathrm{l},(168.7 \mathrm{mg} / \mathrm{l}$ mean) than the furniture effluents with values between 27.7 $116.2 \mathrm{mg} / \mathrm{l}$ (63.6 mg/l mean) (Fig. 6).

During the hot season, lower values of $\mathrm{Cl}^{-}$ were usually recorded as compared to the cold season, which might be caused by dilution during the rainy season. During 2007, the printing effluents recorded the highest fluctuations (Fig. 6). Legislation limits the $\mathrm{Cl}^{-}$concentration level to 500 $\mathrm{mg} / \mathrm{l}$ in surface water withdrawals, and this limit was not surpassed by any of the analysed effluents. This demonstrated that there was no threat for the aquatic life as a result of the discharge of these effluents into the Somesul Mic River. In the study conducted by Tripathi et al., 1991 similar $\mathrm{Cl}^{-}$levels were registered.

\section{Sulphate}

Another threat to aquatic life is the high levels of hydrogen sulphide that result from deficient oxygen conditions and high levels of sulphate $\mathrm{SO}_{4}{ }^{2-}$ or organic materials (Hannan et al., 2011). Consequently, ofgreatimportance is the continuous $\mathrm{SO}_{4}{ }^{2-}$ monitoring. In the printing related effluents, the $\mathrm{SO}_{4}{ }^{2-}$ concentration was between $9.2-72.2 \mathrm{mg} / \mathrm{l}$ ( $47.9 \mathrm{mg} / \mathrm{l}$ mean), while in the furniture ones $\mathrm{SO}_{4}{ }^{2-}$ levels were between 26.7 - $87.9 \mathrm{mg} / \mathrm{l}(65.6 \mathrm{mg} / \mathrm{l}$ 


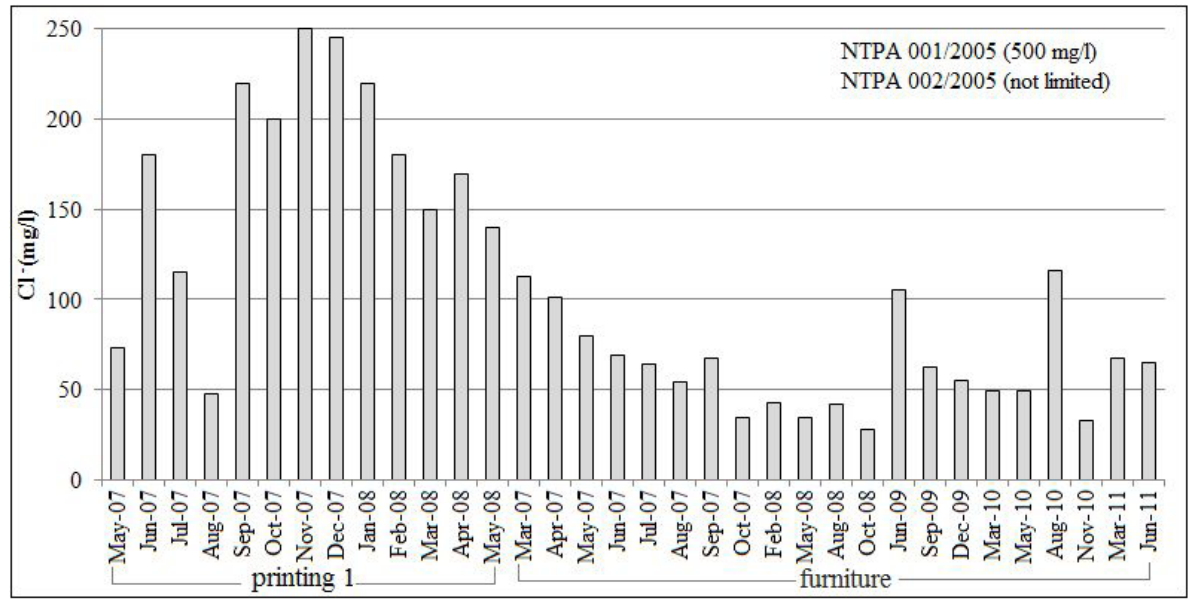

Fig. 6. Chloride $\left(\mathrm{Cl}^{-}\right)$content of the analysed effluents

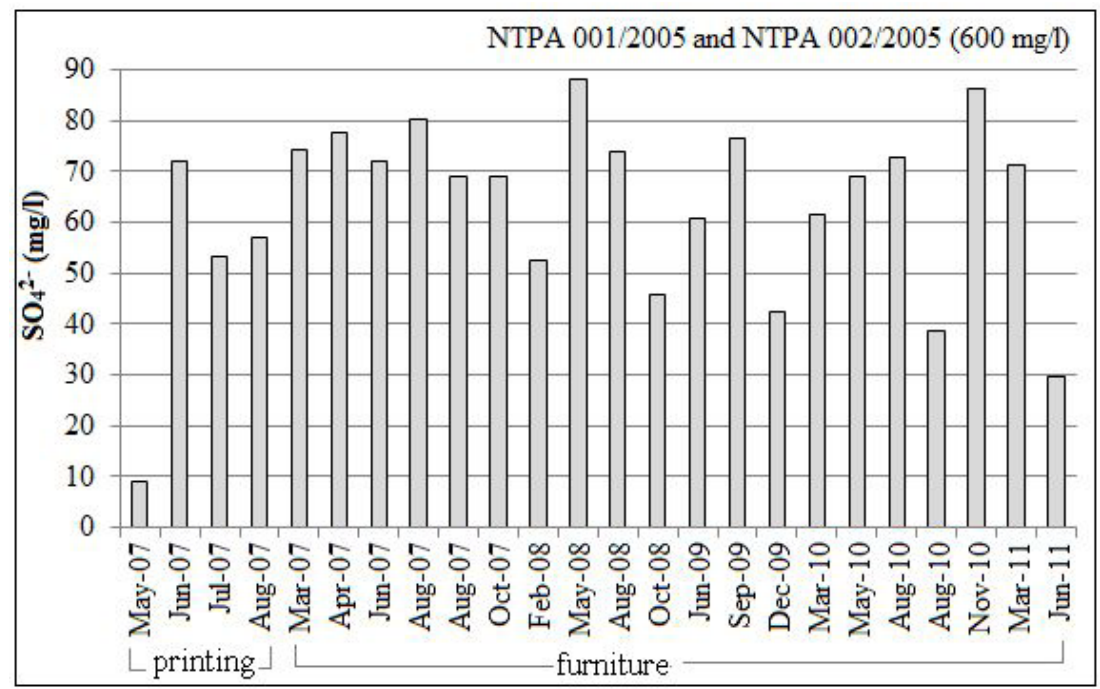

Fig. 7. Sulphate $\left(\mathrm{SO}_{4}^{2-}\right)$ level of the analysed effluents

mean) (Fig. 7). Monthly fluctuations of $\mathrm{SO}_{4}{ }^{2-}$ level were not significant except the printing sample from May 2007. As proven by data in Figure 7, the $\mathrm{SO}_{4}{ }^{2-}$ levels in all the effluents were lower than 600 $\mathrm{mg} / \mathrm{l}$, the permissible limit for surface water and sewage network discharge. So we can conclude that in the analysed effluents, the presence of $\mathrm{SO}_{4}{ }^{2-}$ does not present a risk for aquatic life.

Petroleum ether extractible substances

Generally speaking, water insoluble organic materials include oils, greases, waxes, surfactants, fatty acids, petroleum hydrocarbons, and a variety of other substances from chemical manufacturing and other various industrial processes.

In our research, the concentration of PEES found was between $2.5-39 \mathrm{mg} / \mathrm{l}$. The second printing effluents registered the highest values between 9.5 - $39 \mathrm{mg} / \mathrm{l}$ (20.6 mg/l mean). While the first printing effluents and the furniture effluents had lower concentrations, for the former between 3.5 - $15.7 \mathrm{mg} / \mathrm{l}$ ( $8.6 \mathrm{mg} / \mathrm{l}$ mean), and for the latter between $2.5-20.2 \mathrm{mg} / \mathrm{l}$, (11.3 $\mathrm{mg} / \mathrm{l}$ mean), the plastics effluents registered the lowest levels between $3.5-4.2 \mathrm{mg} / \mathrm{l}$ (3.9 mg/l mean) (Fig. 8). In the second printing and the furniture effluents, the PEES level exceeded the permissible limit for effluents discharge in surface water.

Some of these water insoluble organic materials are volatile, being potential air pollution sources. Annual average temperature and wind speed are important meteorological conditions (US-EPA, 2002) to be taken into consideration.

Due to fact that some molecules have higher kinetic energy, liquids are able to evaporate at any 


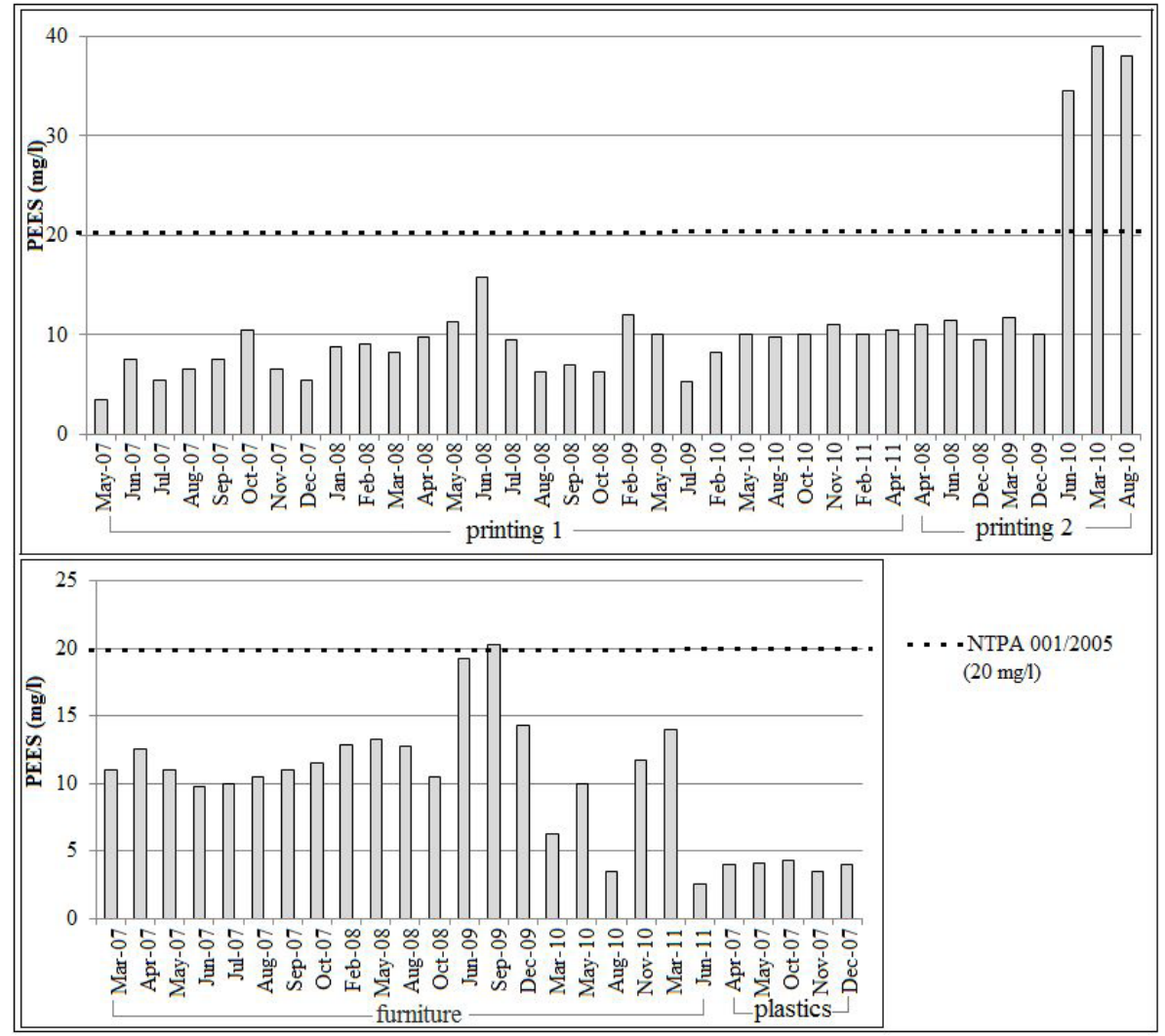

Fig. 8. Petroleum ether extractible substance (PEES) level in the analysed effluents

temperature. As the liquid temperature increases, evaporation also increases. The consequence of high temperatures in long dry seasons leads to different organic pollutants being released from effluents into the air.

\section{Detergents}

Detergents are often used in the textile and other azo-dye related industries. Detergents are organic compounds, which have both polar and non-polar characteristics. There are two kinds of detergents with different characteristics: phosphate and surfactant detergents. The surfactant detergents are used to enhance the wetting, foaming, dispersing and emulsifying properties of detergents, and the phosphate detergents are used to soften hard water and help suspend dirt in water. The detergents that contain phosphates are highly caustic, while the surfactant detergents are very toxic (Adewoye, 2010).

Studies have shown that at a level of $15 \mathrm{mg} / \mathrm{l}$ of detergents, most fish die, while concentrations up to $5 \mathrm{mg} / \mathrm{l}$ will kill fish eggs (Adewoye, 2010). Another problem caused by the presence of detergents in water is that they lower the surface tension of the water, which will increase the absorption of organic chemicals, such as pesticides and phenols by the fish.

In the present study, the detergents level of the analysed effluents ranged between $0.04-0.32$ $\mathrm{mg} / \mathrm{l}$, higher in printing/furniture (between 0.1 - $0.32 \mathrm{mg} / \mathrm{l}$, with a mean value of $0.2 \mathrm{mg} / \mathrm{l}$ ) and plastics $(0.2-0.32 \mathrm{mg} / \mathrm{l}$, with a mean value of 0.27 $\mathrm{mg} / \mathrm{l})$ effluents than in the textile effluents $(0.04$ $0.2 \mathrm{mg} / \mathrm{l}$, with a mean value of $0.12 \mathrm{mg} / \mathrm{l}$ ) (Fig. 9).

There are studies (Jobling and Sumpter, 1993; Ogundiran et al., 2007; Adewoye, 2010) which have proved that even the detergents considered perfectly biodegradable degrade poorly in waters, and they can bio accumulate in plant and animal tissue reaching level which may be toxic to aquatic fauna and flora, and can also induced severe damage to vital organs and even haematological, hormonal and enzyme disturbance.

\section{CONCLUSION}

The data of the present study showed that the analysed physicochemical parameters varied significantly with the effluent source.

The study indicated a seasonal variation for several parameters, dictated by the manufacturer' 


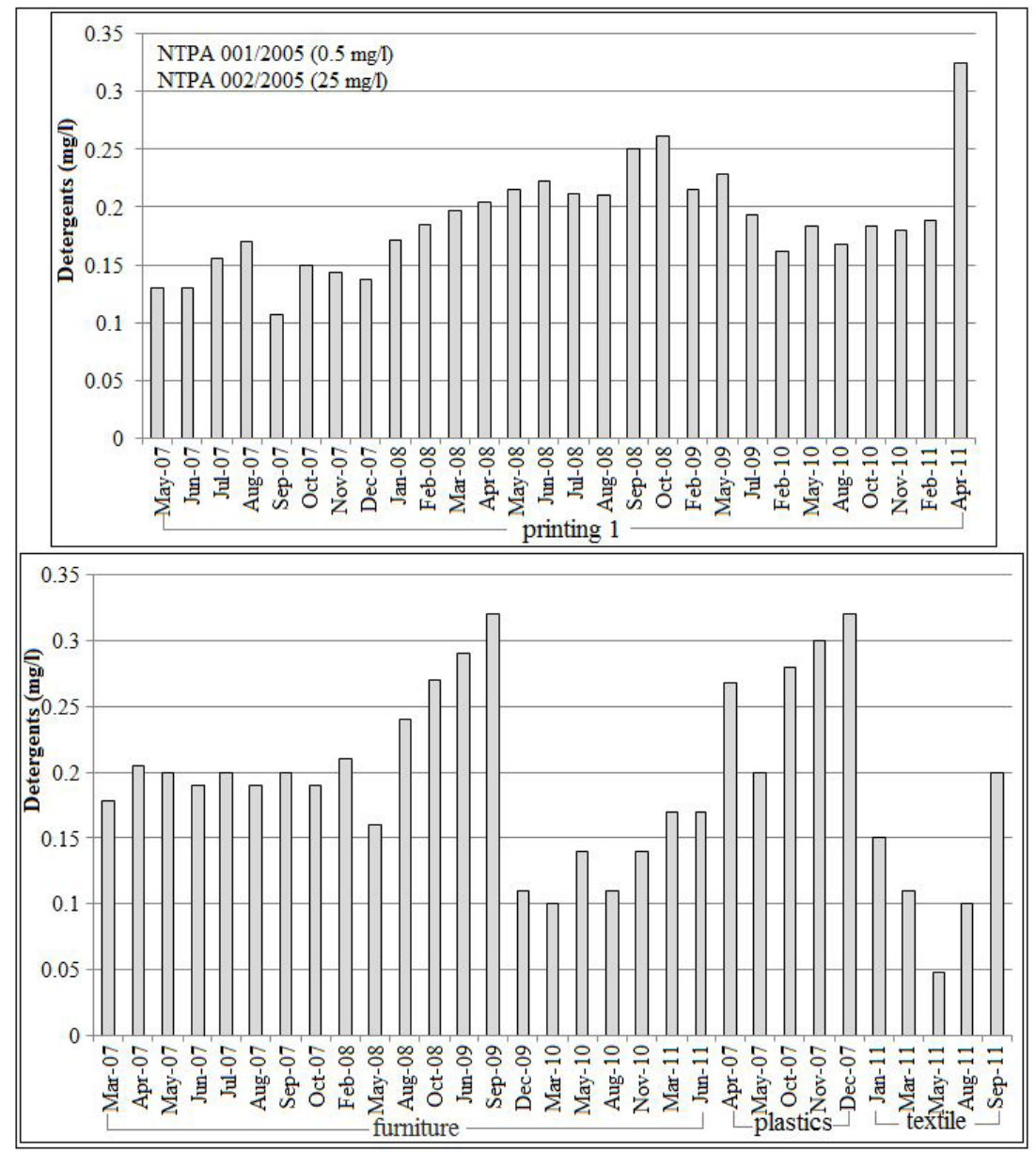

Fig. 9. Detergents content of the analysed effluents

production schedule. In many cases, the quality of the studied effluents was below the limits set by Romanian and UE legislation. The total dissolved solids, chloride, sulphate and detergents content of the effluents were within the permissible limits for surface water discharge, while the other parameters exceeded the limits set by legislation. The most significant permissible limit excesses were recorded in the second printing and textile effluents proving that their discharge into the Somes River or the sewage system (finally ending in the surface waters, too) can seriously affect the aquatic ecosystem. Such polluted effluents must be treated properly before their discharge into surface water or the sewerage network in order to minimize their effect on the aquatic ecosystem.

\section{REFERENCES}

1. Adewoye SO (2010). Effects of detergent effluent discharges on the aspect of water quality of ASA River Ilorin, Nigeria. Agric Biol J N Am 1(4):731-736.
2. Akan JC, Abdulrahman FI, Dimari GA, Ogugbuaja VO (2008). Physicochemical determination of pollutants in wastewater and vegetable samples along the Jakara wastewater Channelin Kano Metropolis, Kano State, Nigeria. Eur J Sci Res 23(1):122-133.

3. Argo B (2003). Understanding $\mathrm{pH}$ management and plant nutrition part 1: Introduction. Int Phalaenopsis Alliance J 12(4):1-2.

4. Campbell KL, Edwards DR (2001). Phosphorus and water quality impacts, p.91-109. In: Ritter WF, Shirmohammadi A (Eds.). Agricultural Nonpoint Source Pollution: Watershed Management and Hydrology. CRC Press, Boca Raton, Florida.

5. Chambers PA, Guy M, Roberts ES, Charlton MN, Kent R, Gagnon C, Grove G, Foster N (2001). Nutrients and their impact on the Canadian environment (Minister of Public Works and Government Services Canada).

6. Codd GA (2000). Cyanobacterial toxins, the perception of water quality and the prioritization of eutrophication control. Ecol Eng 16(1):51-60.

7. Delee W, Niel CO, Hawkes FR, Pinheiro HM (1998). Anaerobic treatment of textile effluents: A Review. J Chem Tech Biotechnol 73:323-325. 
8. Francis-Floyd R, Watson C, Petty D, Pouder BD (1990). Ammonia in aquatic systems, FA16, p 1-5, http://edis. ifas.ufl.edu/pdffiles/FA/FA03100.pdf

9. Hannan MA, Rahman MA, Haque MF (2011). An investigation on quality characterization and magnitude of pollution implications with textile dyeing industries' effluents using bleaching powder. Duet Journal 1(2):4959.

10. Jobling S, Sumpter JP (1993). Detergent components in sewage are waekly oestrogenic to fish: An in vitro study using rainbow trout (Oncorhynchus mykiss) hepatocytes. Aquat Toxicol 27(3-4):361-372.

11. Kanna V, Ramesh R, Sasikumar C (2005). Study on ground water characteristics and the effects of discharged effluents from textile units at Karur Disctrict. $J$ Environ Biol 26(2):262-272.

12. Kumar A (1989). Environmental chemistry. Wiley Eastern Limited, New Delhi, India.

13. Mathur N, Bhatnagar P, Nagar P, Bijarnia MK (2005). Mutagenicity assessment of effluents from textile/ dye industries of Sanganer, Jaipus (India): a case study. Ecotoxicol Environ Saf 61(1):105-113.

14. Nergis Y, Sharif M, Akhtar NA, Hussain A (2009). Quality characterization and magnitude of pollution implication in textile mills effluents. Journal of Quality and Technology Management 5(11):27-40.

15. Nosheen S, Nawaz H, Rehman K (2000). Physico-chemical characterization of effluents of local textile industries of Faisalabd, Pakistan. Int J Agr Biol 2(3):232-233.

16. Ogundiran MA, Fawole O0, Adewoye SO (2007). Effects of soap detergent effluents on the heamatological profiles of Clarias gariepinus. Science Focus 12(1):84-88.

17. Peirce JJ, Weiner RF, Vesilind PA (1997). Environmental pollution and control, p.57-74, Butterworth-Heinemann, Woburn, MA, 4th Edition USA.
18. Roșu C, Piștea I, Roba C, Mihu M, Ozunu A (2014). Surface water quality assessment. Case study: Târnava Mare river, Mediaș Town-Romania. Indian J Appl Res 4(5):70-72.

19. Roy R, Fakhruddin ANM, Khatun R, Islam MS, Ahsan MA, Neger AJMT (2010). Characterization of textile industrial effluents and its effects on aquatic macrophytes and algae. Bangladesh J Sci Ind Res 45(1):79-84.

20. Šostar-Turk S, Simonič M, Petrinić I (2005). Wastewater treatment after reactive printing. Dyes Pigments 64(2):147-152.

21. Tripathi BD, Sikandar M, Shukla SC (1991). Physicochemical characterization of city sewage discharged into river Ganga at Varanasl, India. Environ Int 17:469-478.

22. United States Environmental Protection Agency (US-EPA) (2002). Industrial waste air model technical background document 530-R-02-010.

23. Voutsa D, Manoli E, Samara C, Sofoniou M, Stratis I (2001). A study of surface water quality in Macedonia, Greece: specification of nitrogen and phosphorus. Water Air Soil Poll 129(1-4):13-32.

24. Wells MJM, Rossano AJ, Roberts EC (1994). Textile wastewater effluent toxicity identification evaluation. Arch Environ Contam Toxicol 27:555-560.

25. Wetzel RG (2001). Limnology: Lake and river ecosystems, 3rd edition. Academic Press, San Diego CA, 985 p.

26. Yusuff RO, Sonibare JA (2004). Characterization of textile industries effluents in Kaduna, Nigeria and pollution implications. Global Nest: The Int J 6(3):212-221.

27. Zorpas AA, Inglezakis VJ, Stylianou M, Voukkali I (2010). Sustainable treatment method of a high concentrated $\mathrm{NH} 3$ wastewater by using natural zeolite in closed-loop fixed bed systems. Open Environmental Sciences 4:1-7. 